\title{
Potential of Hollow Glass Microsphere as Cement Replacement for Lightweight Foam Concrete on Thermal Insulation Performance
}

\author{
Shahiron Shahidan ${ }^{1, *}$, Eeydzah Aminuddin ${ }^{2}$, Khairiyah Mohd Noor ${ }^{1}$, Nurul Izzati Raihan \\ Ramzi Hannan ${ }^{1}$, and Nur Amira Saiful Bahari ${ }^{1}$ \\ ${ }^{1}$ Jamilus Research Centre, Faculty of Civil and Environmental Engineering, Universiti Tun Hussein \\ Onn Malaysia \\ ${ }^{2}$ Faculty of Civil Engineering, Universiti Teknologi Malaysia, Skudai, Johor, Malaysia
}

\begin{abstract}
Global warming can be defined as a gradual increase in the overall temperature of the earth's atmosphere. A lot of research work has been carried out to reduce that heat inside the residence such as the used of low density products which can reduce the self-weight, foundation size and construction costs. Foamed concrete it possesses high flow ability, low self-weight, minimal consumption of aggregate, controlled low strength and excellent thermal insulation properties. This study investigate the characteristics of lightweight foamed concrete where Portland cement (OPC) was replaced by hollow glass microsphere (HGMs) at $0 \%, 3 \%, 6 \%$, $9 \%$ by weight. The density of wet concrete is $1000 \mathrm{~kg} / \mathrm{m} 3$ were tested with a ratio of 0.55 for all water binder mixture. Lightweight foamed concrete hollow glass microsphere (HGMs) produced were cured by air curing and water curing in tank for 7, 14 and 28 days. A total of 52 concrete cubes of size $100 \mathrm{~mm} \times 100 \mathrm{~mm} \times 100 \mathrm{~mm}$ and $215 \mathrm{~mm} \times 102.5 \mathrm{~mm} \times 65 \mathrm{~mm}$ were produced. Furthermore, Scanning Electron Microscope (SEM) and X-ray fluorescence (XRF) were carried out to study the chemical composition and physical properties of crystalline materials in hollow glass microspheres. The experiments involved in this study are compression strength, water absorption test, density and thermal insulation test. The results show that the compressive strength of foamed concrete has reached the highest in 3\% of hollow glass microsphere with less water absorption and less of thermal insulation. As a conclusion, the quantity of hollow glass microsphere plays an important role in determining the strength and water absorption and also thermal insulation in foamed concrete and 3\% hollow glass microspheres as a replacement for Portland cement (OPC) showed an optimum value in this study as it presents a significant effect than other percentage.
\end{abstract}

* Corresponding author: shahiron@uthm.edu.my 


\section{Introduction}

In a concrete structure, self-weight represents a very large proportion of the total load on the structure, and clearly there are advantages in reducing the density of concrete $[1,2]$. Foamed concrete was widely used and has been used as an insulation material since 1923, where the first comprehensive review on foamed concrete was presented by [23] and a detailed treatment by [24], summarizing the its composition and properties, significant improvements over the past 20 years in production equipment and better quality surfactants (foaming agents) have enabled the use of foamed concrete on a larger scale [3, 4].

Foamed concrete is used for a variety of applications, ranging from thermal insulation and fire protection to void-filling and building elements with successively increasing density and strength requirements, such as, an insulating fill in fire walls or other precast elements, a replacement for soils and backfills, and the construction of cast-in-place piles.

Lightweight concrete application in construction reduces building costs, eases construction and has the advantage of being a relatively 'green' building material [5]. Since it can be classified as an ideal material for residential construction which can prevent the heat level for buildings from increasing due to global warming, thermal insulation properties offer the advantage of functionality and being cost effective for house building projects in particular [6]. In addition, a product of low density reduces its own weight, the size of the foundation, and construction costs [7].

According to [9], Hollow Glass Microspheres (HGMs) seem to be a new and innovative product low in density, which can survive extremely high compressive forces, providing compounders and processors with new application opportunities [8-11]. HGMs are being developed in various sizes which possess light weight and high strength under hydrostatic pressure HGMs consist of an outer stiff glass and an inner inert gas, which results in some unique properties, such as being light in weight and having low thermal conductivity. These spheres might be expected to form a good inclusion system for the purpose of increasing the elastic stiffness of a soft light-weight matrix [10, 12, 17]. HGMs modified to replace aggregates as an additive will have a lower density, improved compressive strength and lower thermal insulation. Therefore, it is believed that the compressive strength of the lightweight concrete can be improved by modifying the HGMs into lightweight concrete, where HGMs can be used as cement replacement due to chemical properties. It also have a potential in thermal insulation and the effect can be determined by using difference percentages of HGMs as cement replacement in lightweight foamed concrete. Therefore this research will be mainly emphasized on lightweight foamed concrete using HGMs material for insulation. The objective of this paper is to determine the engineering properties of the lightweight foam concrete contain HGMs material as a cement replacement.

\section{Hollow glass microspheres (HGMs)}

Low densities of Hollow Glass Microspheres (3MTM Glass Bubble) are often referred to as shells, microballons, shirasuballons, vesicles and microcapsules. These hollow glass microspheres use as a density reducing agent for oil and gas drilling fluids and drilling cements and also can be used as a low-density filler material that is ideal for plastic and rubber parts created from compression moulding, extrusion processes and or other vigorous processing equipment [7]. Hollow spheres are used as lightweight filler in composite materials such as syntactic foam and lightweight concrete. With good thermal insulation properties and resistance to the external impact and help to reduce weight, reduce noise, vibration and harmonics, reduce thermal expansion [9]. Microspheres are usually white or grey in colour, and several manufacturers offer various inorganic hollow microspheres. The 
wall thicknesses of the particles are generally $10 \%$ of their diameter $[10,15,16]$. There is a characteristic of Hollow Glass Microspheres showed in Table 1.

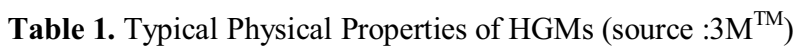

\begin{tabular}{|c|c|}
\hline Properties & $\mathbf{3 M}^{\mathbf{T M}}$ Glass Bubbles iM30K \\
\hline Chemical resistance & $\begin{array}{c}\text { chemical properties of 3M glass bubbles } \\
\text { resemble those of a soda-lime borosilicate } \\
\text { glass }\end{array}$ \\
\hline Isostatic crush strength (psi) & 28,000 \\
\hline True density (g/cc) & 0.60 \\
\hline $\begin{array}{c}\text { Packing factor (bulk density to true } \\
\text { particle density) }\end{array}$ & $63 \%$ \\
\hline $\begin{array}{c}\text { Oil absorption (g oil/100 cc of polymer } \\
\text { additive) }\end{array}$ & 33.5 \\
\hline Softening point $\left({ }^{\circ} \mathrm{C}\right)$ & 600 \\
\hline Floatation (density) & $90 \%$ (in volume) \\
\hline Volatile content (by weight) & $0.5 \%$ (max) \\
\hline Alkalinity (miliequaivalent/gram max) & 0.5 \\
\hline
\end{tabular}

\section{Materials and methods}

The material required in this study is foam, cement, fine aggregate and water and Hollow Glass Microsphere (HGMs). The HGMs was tested with SEM and XRF to identify the surface and the chemical composition respectively. The concrete mixes are determined using ratio $2: 1$ which represent cement to sand and water cement ratio at $0.55 \%$ for cement slurry foam production. The cement slurry foamed was poured in cubic moulds which was size $100 \mathrm{~mm} \times 100 \mathrm{~mm} \times 100 \mathrm{~mm}$ and curing for 7,14 and 28 days. The total 53 cubes specimens were tested for compressive strength, water absorption and thermal conductivity at $215 \mathrm{~mm} \times 102.5 \mathrm{~mm} \times 65 \mathrm{~mm}$ in volume. The replacement of cement with HGMs is varied from $\mathrm{M} 1: 0 \%, \mathrm{M} 2: 3 \%, \mathrm{M} 3: 6 \%$ and $\mathrm{M} 4: 9 \%$. These were done to determine the proportion that would give the most favourable result. The $0 \%$ served as control for other sample. In this study, the tests have been carried out to ensure the acceptance of HGMs as replacement cement for binder in lightweight foamed concrete mixture.

\section{Results and discussion}

\subsection{Physical and chemical properties}

Fig. 1 shows the SEM image of Hollow Glass Microspheres. The results suggest a smooth clean surface, which would not promote interfacial adhesion between the filler material and polymer matrix. A perfectly spherical shape with an aspect ratio of one makes glass bubbles efficient volume fillers. While Table 2 and Table 3 shows the chemical composition of HGMs and Portland cement.

\subsection{Density}

Fig. 2 represent the dry densities of foamed concrete fluctuate when the HGMs are added into the foam concrete. It shows that the plastic densities of concrete mortar before being 
added to the foam concrete were very high. The mixture's density may be slightly lower than normal concrete density due to the HGMs added into the mortar mixtures.

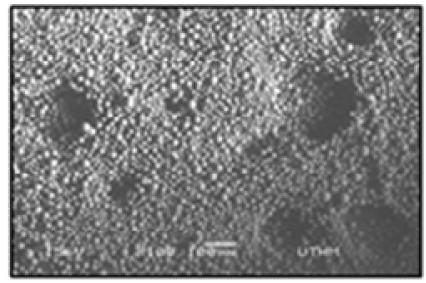

(a)

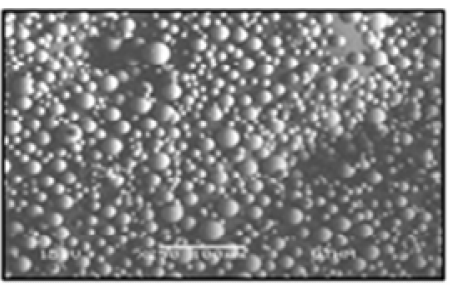

(b)

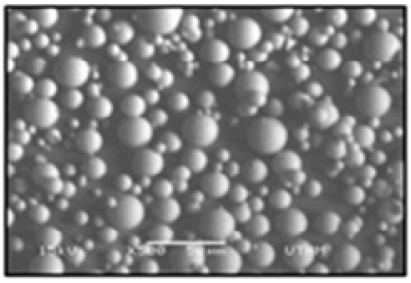

(c)

Fig. 1. SEM of HGMs: (a) $100 \mu \mathrm{m} 100 \mathrm{x}$ Mag; (b) $100 \mu \mathrm{m} 250 \mathrm{x}$ Mag; (c) $50 \mu \mathrm{m}$ 500x Mag.

Table 2. Chemical composition of HGMs

\begin{tabular}{|c|c|}
\hline Chemical Composition & Concentration (\%) \\
\hline $\mathrm{SiO}_{2}$ & 65.30 \\
\hline $\mathrm{CaO}$ & 13.40 \\
\hline $\mathrm{Na}_{2} \mathrm{O}$ & 5.92 \\
\hline $\mathrm{C}$ & 0.10 \\
\hline $\mathrm{P}_{2} \mathrm{O}_{5}$ & 0.59 \\
\hline $\mathrm{SO}_{3}$ & 0.27 \\
\hline $\mathrm{Al}_{2} \mathrm{O}_{3}$ & 0.26 \\
\hline
\end{tabular}

Table 3. Chemical composition of Portland Cement

\begin{tabular}{|c|c|}
\hline Chemical Composition & Concentration (\%) \\
\hline $\mathrm{SiO}_{2}$ & 21.06 \\
\hline $\mathrm{CaO}$ & 57.98 \\
\hline $\mathrm{Al}_{2} \mathrm{O}_{3}$ & 6.10 \\
\hline $\mathrm{Fe}_{2} \mathrm{O}_{3}$ & 3.08 \\
\hline $\mathrm{MgO}$ & 2.74 \\
\hline $\mathrm{SO}_{3}$ & 2.40 \\
\hline $\mathrm{Loss}$ & 4.07 \\
\hline
\end{tabular}

After the addition of foam into mortar mixtures, the densities of the mixture decreased significantly. It is because the foam agent occupies the space in the mortar mixtures known as voids. The consistency of the mix to which the foam is added is important, as this consistency affects the stability of the mix. Consistency is significantly reduced when foam is added. $[13,16]$.

According to Hamidah et al [18], a lower density foamed concrete can achieve a strength equal to that of a higher density foamed concrete by increasing the cement content. The control sample decreased from $1000 \mathrm{~kg} / \mathrm{m}^{3}$ to $943 \mathrm{~kg} / \mathrm{m}^{3}$. This may be due to the drying air content in concrete [19]. The results show that the more HGMs are added to the 
sample, the more concrete density decreases. This may be because cement and HGMs possess different weight.

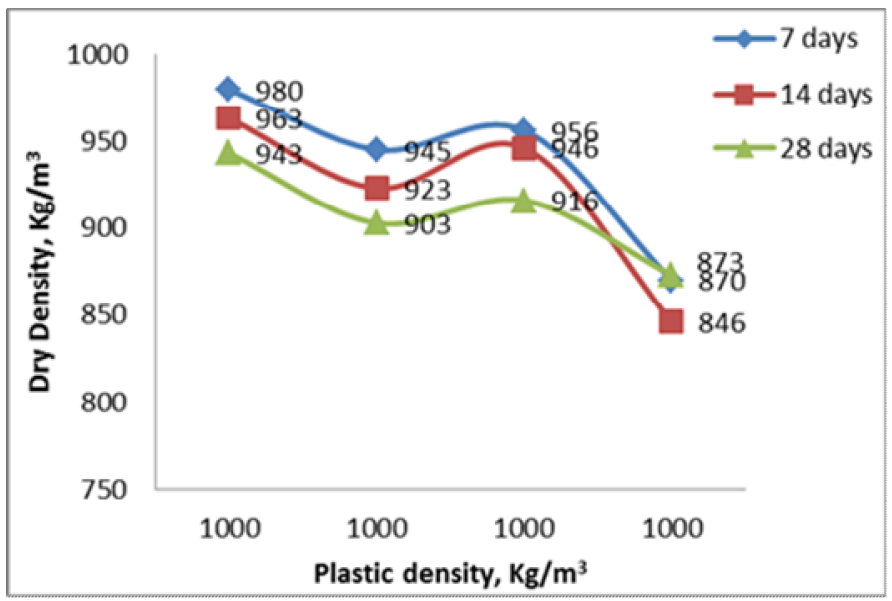

Fig. 2. Comparison between plastic density and dry density of foamed concrete at 7, 14 and 28 days

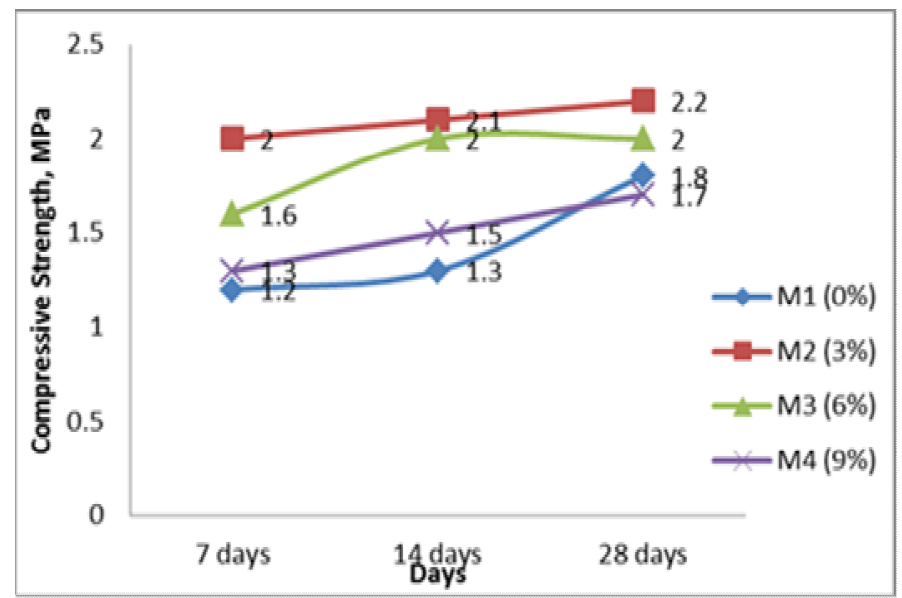

Fig. 3. The compressive strength against the days of curing.

\subsection{Compressive strength and water absorption}

The comparison of compressive strength of foamed concrete at 7, 14 and 28 days is shown in Fig. 3. The different percentages of HGMs have affected the compressive strength of the concrete. The result show the compressive strength of foamed concrete is fluctuated which is the maximum strength of concrete is M2 where its compressive strength recorded is 2.2 MPa with $3 \%$ of HGMs at density $998 \mathrm{~kg} / \mathrm{m}^{3}$, M3 $2.1 \mathrm{MPa}$ with $6 \%$ at density $916 \mathrm{~kg} / \mathrm{m}^{3}$ and the minimum strength is M4 which is compressive strength $1.7 \mathrm{MPa}$ with $9 \%$ of HGMs. These values are quite good compared with compressive strength reported by [16] for foamed concrete ( 2 to-18MPa at density of 1000 to $1500 \mathrm{~kg} / \mathrm{m}^{3}$ ) at where the sample were replacement of cement (up to $75 \%$ by weight) with both classified and unclassified fly ash. 
The compressive strength of foamed concrete in 28 days has increase significantly compare to the compressive strength at 7 and 14 days. It may be due to the different percentage of HGMs used in the foamed concrete and also influenced by the physical properties of HGMs; this is because the strength development with exposure to natural weathering was crucially dependent on the humidity and temperature changes $[14,15,20]$. While, table 4 shows the percentage of water absorbed by HGMs foamed concrete with different curing days. The percentage of water absorbed in the foam concrete was influenced by the different percentage of HGMs used which is M2 where 3\% of HGMs used was absorbed less water than other mixture. Meanwhile, M4 with 9\% of HGMs achieved the highest absorption. This may be due to the higher percentage of air void and effect of HGMs foamed concrete. Therefore, when the higher percentage of air void occurred, the more the water immersed into the foamed concrete. It can be seen that, water absorption increased when the percentage of HGMs is increased. Fig. 4 show the comparison of percentage of water absorption of foamed concrete at 28 days.

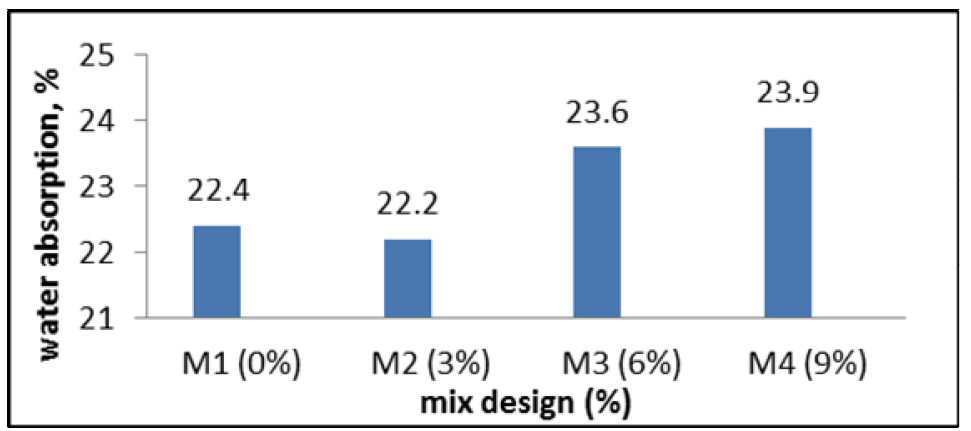

Fig. 4. Percentage of water absorption of foamed concrete at 28 days.

Table 4. water absorption of foamed concrete at 28 days.

\begin{tabular}{|c|c|c|c|}
\hline \multirow{2}{*}{ Mix Design } & \multicolumn{3}{|c|}{ Water absorption of foamed concrete for 28 days } \\
\cline { 2 - 4 } & $\begin{array}{c}\text { Oven Dry Density } \\
\left(\mathbf{K g} / \mathbf{m}^{3}\right)\end{array}$ & $\begin{array}{c}\text { Immersed Density } \\
\mathbf{K g} / \mathbf{m}^{3}\end{array}$ & $\begin{array}{c}\text { Percentage } \\
\text { Absorption }(\%)\end{array}$ \\
\hline M1 (0\% HGM) & 983 & 1203 & 22.4 \\
\hline M2 (3\% HGM) & 930 & 1136 & 22.2 \\
\hline M3 (6\% HGM) & 906 & 1120 & 23.6 \\
\hline M4 (9\% HGM) & 836 & 1036 & 23.9 \\
\hline
\end{tabular}

\subsection{Thermal conductivity}

Table 5 shows the result of the thermal conductivity testing of three different percentages of Hollow Glass Microsphere (HGMs) and the dry density of concrete. After adding The HGMs the result shows that the k-value was decrease. The result of foam concrete that was added by $3 \%$ of the HGMs was almost same as the result with the control sample which is $0.25 \mathrm{w} / \mathrm{mk}$. but when the HGMs were added at $6 \%$ the result decrease to $0.20 \mathrm{w} / \mathrm{mk}$. from this result, from Figure. 5 (a) it can be see the HGMs in foamed concrete have a potential in thermal insulation for concrete construction. From the previous research, Saygili and 
Baykal [21] reported that the decrease in the thermal conductivity is due to the increase of void ratio that decreased the unit weight of concrete. Since air is the poorest conductor compared to the solid and liquid due to its molecular structure [22], it contributes to the lower thermal conductivity in porous concrete. Also, Ramamurthy et al. [16] reported that foamed concrete has excellent thermal insulating properties due to its cellular microstructure. From the result, it was found that the optimum HGMs content is $3 \%$ with the average range of thermal conductivity of $0.2596 \mathrm{~W} / \mathrm{mK}$ with highest compressive strength value of $2.2 \mathrm{MPa}$. The thermal conductivity of M2 almost similar as M1(control sample) but for the compressive strength, the M1 and M2 show the large margin which was 2.0 to $2.2 \mathrm{MPa}$ with thermal conductivity below than $0.3 \mathrm{w} / \mathrm{mk}$ its quite good result for used HGMs in foamed concrete. Fig. 5 (b) shows the graft the effect of HGMs on mechanical properties and thermal conductivity.

Table 5. Thermal conductivity test result

\begin{tabular}{|c|c|c|c|}
\hline \multirow{2}{*}{ Mix Design } & \multicolumn{3}{|c|}{ Thermal conductivity of different HGMs Percentage for 28 days } \\
\cline { 2 - 4 } & $\mathrm{M} 1(0 \%)$ & M2 (3\%) & M3 (6\%) \\
\hline Density $\left(\mathrm{Kg} / \mathrm{m}^{3}\right)$ & 970 & 998 & 984 \\
\hline Thermal $(\mathrm{w} / \mathrm{mk})$ & 0.2507 & 0.2596 & 0.2029 \\
\hline
\end{tabular}

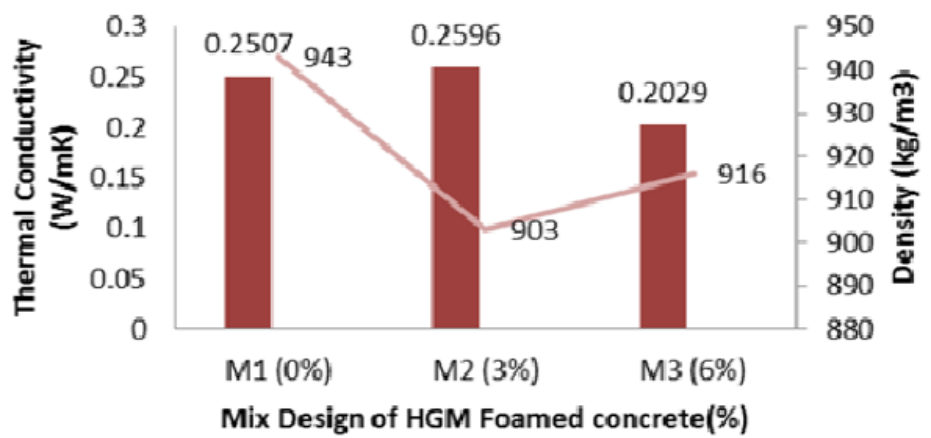

Fig. 5 (a). Thermal conductivity against density of HGMs foamed concrete.

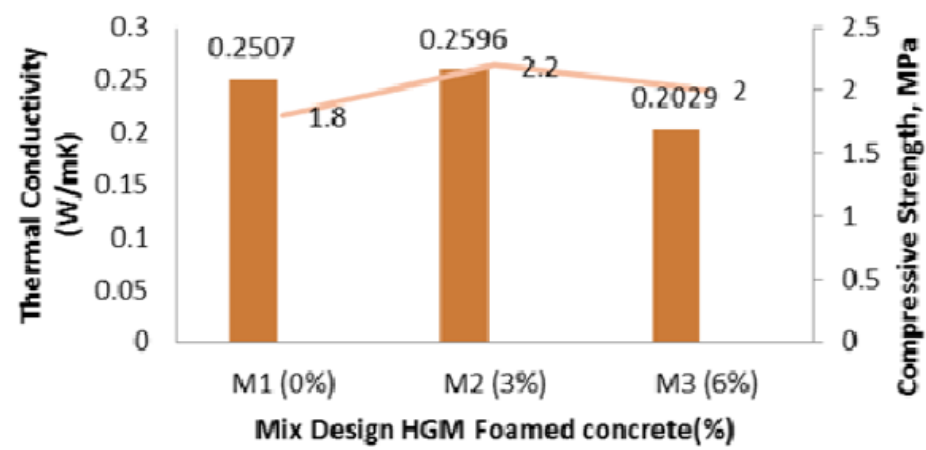

Fig. 5 (b). Effect of HGMs on mechanical properties and thermal conductivity. 


\section{Conclusions}

The conclusion as follows:

- The result gained from this study shows that the Hollow Glass Microsphere foamed concrete has a range density of between $900 \mathrm{~kg} / \mathrm{m} 3$ and $1000 \mathrm{~kg} / \mathrm{m} 3$.

- The optimum percentage of the usage of HGMs as partial replacement of cement in foamed concrete is 3\% due its compressive strength is higher than other percentage of HGMs.

- The percentage of water absorption of Hollow Glass Microsphere foamed concrete on 28 days were between $22.2 \%$ and $23.9 \%$.

- The thermal conductivity of HGMs foamed concrete decrease after added the HGMs by percentage $3 \%, 6 \%$ and $9 \%$.

A further research of the properties and the potential of the HGMs should be carried out since the HGMs may contain the chemical material which will infiltrate the water body and hence affecting the ground and environment.

The authors would like to express their deepest appreciation to the Ministry of Higher Education Malaysia, Universiti Tun Hussein Onn Malaysia for funding the research under grant U523.

\section{References}

[1] E.K Nambiar, K. Ramamurthy, Influence of filler type on the properties of foam concrete, Cement and Concrete Composites, 28(5), 475-480, (2006)

[2] S. Shahidan, H.B. Koh, A.M.S. Alansi, L.Y. Loon, Strength development and water permeability of engineered biomass aggregate pervious concrete, MATEC Web Conf., 47, 2-7, (2016)

[3] S. Shahidan, S.S.M. Zuki, N. Jamaluddin, Damage grading system for severity assessment on concrete structure, Case Stud. Constr. Mater., 5, 79-86, (2016)

[4] M.A. Rahim, Z. Ghazaly, R.Nurazira, R. Mamat, M.A. Azizan, N.F. Isa, S. Shahidan, Experimental study of slurry infiltrated fiber reinforced concrete, Material Science Forum, 857, 363-366, (2016)

[5] T.Y. Lo, W.C. Tang, H.Z. Cui, The effects of aggregate properties on lightweight concrete, Building and Environment, 42, 3025-3029, (2007)

[6] N. Ali, K.Y. Yaacob, S. Shahidan, S.R. Abdullah, Investigation of compressed earth brick containing ceramic waste, ARPN J. Eng. Appl. Sci., 11(8), 5459-5462, (2016)

[7] J. Alduaij, K. Alshaleh, M.N. Haque, K. Ellaithy, Lightweight concrete in hot coastal area, Cement and Concrete Composites, 21(5), 453-458, (1999)

[8] S.A. Kudus, N.M. Bunnori, S.R. Basri, S. Shahidan, M.N.M. Jamil, N.M. Noor, An overview current application of artificial neural network in concrete, Advanced Material Research, 626, 372-375, (2012)

[9] A.S. D’Souza, K. Hendrikson, Innovative high strength glass microspheres for extruded and injection molded plastics, The 3rd Int. Conf. High Perform. Fillers, (2007)

[10]K.J. Lee, R.A. Westmann, Elastic properties of hollow-sphere-reinforced composite, University of California, Los Angeles, (1969).

[11]St. Paul, Energy and Advanced Materials Division 3M Center, Building 223-6S-04, Retrieve on October 2016 from http:// www.3m.com.

[12]N. Fredrick, P. Lin, J.K. Koech, Y. Wang, Surface modification of hollow glass microspheres, Materials Science and Application, 856-860, (2012)

[13]N. Md Nor, N. Muhamad Bunnori, A. Ibrahim, S. Shahidan, S.N.M. Saliah, An investigation on acoustic wave velocity of reinforced concrete beam in-plane source, 
Proc. 2011 IEEE 7th Int. Colloquium on Signal Processing and Its Applications, CSPA, 19-22, (2011).

[14]B.W. Sands, W.C. Howes, Hollow glass microspheres - A cost-effective lightweight filler, Plastics Engineering, 38(4), 31-33, (1982)

[15]K. Ramamurthy, E.KK. Nambiar, G. Indu Siva Ranjani, A classification of studies on properties of foam concrete, Cement and Concrete Composites, 31(6), 388-396, (2009)

[16] M.S. Hamidah, I. Azmi, M.R.A. Ruslan, K. Kartini, N.M. Fadhil, Optimisation of foamed concrete mix of different sand-cement ratio and curing conditions, Proc. of Int. Conf. on the use of foamed concrete in construction, 37-44, (2005)

[17] S. Shahidan, R. Pullin, K.M. Holford, M.B.N, N. Nor, Quantitative evaluation of the relationship between tensile crack and shear movement in concrete beams, Advanced Material Research, 626, 355-359, (2013)

[18]E.P. Kearsley, P.J. Wainwright, The effect of high fly ash content on the compressive strength of foamed concrete, Cement and Concrete Research, 31 (1), 105-112, (2001)

[19] S.K. Lim, T.C. Ling, M.W. Hussin, Ground-granulated blast-furnace slag as potential filler in polyester grout: Compressive strength development, ACI Material J., 108, 120-127, (2011)

[20] M. Abdul Rahim, N.M. Ibrahim, Z. Idris, Z.M. Ghazaly, S. Shahidan, N L. Rahim, L. A. Sofri, N. F. Isa, Properties of concrete with different percentange of the rice husk ash (RHA) as partial cement replacement, Material Science Forum, 803, 288-293, (2014)

[21]A. Saygll1, G. Baykal, A new method for improving the thermal insulation properties of fly ash, Energy and Buildings, 43(11), 3236-3242, (2011)

[22] S.C. Ng, K.S. Low, Thermal conductivity of newspaper sandwiched aerated lightweight concrete panel, Energy and Buildings, 42(12), 2452-2456, (2010)

[23]R.C. Valore, Cellular concrete part 1: Composisiton and method of production, ACI Journal, 50, 773-796, (1954)

[24] G. Rudnai, Lightweight concretes, Budapest, Akademi Kiado, (1963) 